\title{
EFFECT OF SIMULTANEOUS ADMINISTRATION OF PGF $2 \alpha$ AND GnRH ON FOLLICULAR DEVELOPMENT, OESTRUS AND THE TIMING OF OVULATION IN COWS
}

\author{
R. DOLEŽEL ${ }^{1}$, R. NOVOTNÝ ${ }^{2}$, S. ČECH ${ }^{1}$, J. ZAJÍC ${ }^{1}$, V. HAVLÍČEK ${ }^{1}$ \\ Department of Animal Reproduction, ${ }^{1}$ Faculty of Veterinary Medicine, \\ University of Veterinary and Pharmaceutical Sciences Brno, Czech Republic
} ${ }^{2}$ SERVIER s. r. o., Prague, Czech Republic

Received June 1, 2000

Accepted November 22, 2000

Abstract

Doležel R., R. Novotný, S. Čech, J. Zajíc, V. Havlíček: Effect of Simultaneous Administration of $\mathrm{PGF}_{2} \alpha$ and GnRH on Follicular Development, Oestrus and the Timing of Ovulation in Cows. Acta Vet. Brno 2000, 69: 289-296.

The aim of this study was synchronization of oestrus in cows by simultaneous administration of $\mathrm{PGF}_{2} \alpha$ and $\mathrm{GnRH}$. Synchronization of oestrus was repeated in 5 cows housed at our department of the university (group I) and 32 cycling cows in dairy farms (group II and III). In total 15 synchronized sexual cycles were observed in group I. Oestrus was synchronized by intramuscular administration of $500 \mu \mathrm{g}$ of cloprostenol (Oestrophan, Ferring-Léčiva, Prague, Czech Republic) and $100 \mu \mathrm{g}$ of lecirelin pro toto (Supergestran, Ferring-Léčiva, Prague, Czech Republic) at the same time during the luteal phase of the sexual cycle. The cows were examined by transrectal ultrasonography daily from the day of treatment to occurrence of a new luteal phase, and ovarian structures were evaluated in group I. Ultrasonographical examination of ovarian structures were performed on the day of treatment (day 0) and on days 3, 7 and 14 and samples of peripheral blood for progesterone determination by ELISA were obtained on days 0,3 and 7 in group II $(n=12)$. Daily detection of oestrus and ultrasonographical examination on days 0,14 and 28 after treatment were performed in group III $(n=20)$. The cows in oestrus were inseminated and conception rate was evaluated in this group. The new follicular wave occurred on the day 3 or 4 in all synchronized sexual cycles and ovulation occurred in 1 synchronized cycle on the day 3 , in 6 cycles between days 7 and 9 and in 6 cycles between days 10 and 17 in group I. Ovulation did not occur and luteal cysts developed in 2 synchronized cycles in group I. Ovulation occurred in 5 cows until day 3 and in 4 cows between days 3 and 14 after treatment in group II. Ovulation was not proved in 3 cows until day 14 and luteal cysts developed in 1 of them. Total concentration of progesterone were $2.40 \pm$ $0.989,0.22 \pm 0.054$ and $0.44 \pm 0.323 \mathrm{ng} / \mathrm{ml}$ on days 0,3 and 7 , respectively. Oestrus occurred most frequently between days 3 and 8 after treatment and total conception rate after insemination was $41 \%$ in group III. Simultaneous administration of $\mathrm{PGF}_{2} \alpha$ and $\mathrm{GnRH}$ during the luteal phase of the sexual cycle does not represent a sufficiently efficient method of synchronization of oestrus in cows. The majority of oestrus and ovulation occurs on days 3 and 8 after treatment.

Cows, $P G F_{2} \alpha, G n R H$, synchronization of oestrus, follicular wave, ovulation, progesterone

Poor rates of oestrus detection combined with poor conception rates represent the main problem in cattle reproduction. Synchronization of oestrus has been helpful in the solution of this problem. This method can remove the necessity of oestrus detection and it makes it possible to provide artificial insemination in the predicted time. But evaluating the exact time of ovulation is a condition for efficient synchronization of oestrus. Traditional method of synchronization of oestrus using $\mathrm{PGF}_{2} \alpha$ or its synthetic analogues during luteal phase of the sexual cycle is accompanied by ovulation in various periods. The time of ovulation depends on the stage of follicular development at the time of $\mathrm{PGF}_{2} \alpha$ treatment (Lars on et al. 1996; $\mathrm{Xu}$ et al. 1997). This stage is variable because the follicular development proceeds in continual repeating follicular waves in 7-10 day intervals (Piers on and Ginther 1987; Sirois and Fortune 1988). The follicular wave represents recruiment and growth of 
cohort (2-6) of the tercial follicles during 2-4 days (phase of the growth), differentiation of a dominant follicle and subordinate follicles (phase of the selection) and further development of the dominant follicle during $4-10$ days while the subordinate follicles undergo atresia and they disappear (phase of the dominance) (Pierson and Ginther 1988; Rajahamendran and Walton 1988; Driancourt 1991). Usually the dominant follicle undergoes atresia in presence of the endogenous progesterone during luteal phase of the sexual cycle or it ovulates in the case of absence of progesterone.

The dynamics of follicular development follows the variability of the time of ovulation after artificial lueolysis. For this reason methods of oestrus synchronization with control of luteal phase as well as follicular development have been developed recently. It was found that administration of GnRH terminates the actual follicular wave (atresia or ovulation of the dominant follicle) and induces the new follicular wave within 3 or 4 days after administration at any stage of the sexual cycle (for review see Twagiramungu et al. 1995). On the base of these data new protocol of synchronization of oestrus was developed in which administration of $\mathrm{GnRH} 7$ days before $\mathrm{PGF}_{2} \alpha$ synchronizes follicular development before luteolysis and gives precise time of ovulation after $\mathrm{PGF}_{2} \alpha$ treatment. In addition the second administration of $\mathrm{GnRH} 2$ days after $\mathrm{PGF}_{2} \alpha$ treatment for the purpose of synchronization of the follicle maturation further specifies the exact time of ovulation (Pursley et al. 1995). It seems that this protocol (Ovsynch; GnRH - 7 days $\mathrm{PGF}_{2} \alpha-2$ days - GnRH) synchronizes follicular development and regression of the corpus luteum as well as the time of ovulation and it allows effective timed artificial insemination without the need for detection of oestrus in dairy cows (Burke et al. 1996; Schmitt et al. 1996; Pursley et al. 1997).

The object of our experiment was to provide a simple method for synchronization of oestrus by simultaneous application of $\mathrm{PGF}_{2} \alpha$ and $\mathrm{GnRH}$ during luteal phase of the sexual cycle. We hypothesized that GnRH in condition of higher concentration of endogeneous progesterone terminates the present follicular wave by atresia and it induces a synchronous recruitment of a new follicular wave. We presumed that new dominant follicle of synchronized follicular wave would ovulate because the dominant follicle of the previous follicular wave would not ovulate and new corpora lutea would not develop after simultaneous administration of $\mathrm{PGF}_{2} \alpha$ and $\mathrm{GnRH}$.

\section{Materials and Methods}

Five cycling dairy cows housed at the Department of Animal Reproduction of the university (group I) and 32 cycling cows in dairy farms (group II and III) after day 60 post partum were used in the experiment. Synchronization of oestrus was repeated in cows of the experimental group I. At least one normal (non-synchronized) sexual cycle past between two synchronized cycles in these cows. Altogether 15 synchronized cycles were observed in group I. Synchronization of oestrus was performed in groups II $(n=12)$ and III $(n=20)$ in cows without any pathological symptoms as well as treatments during postpartum period. Oestrus was synchronized by intramuscular administration of $500 \mu \mathrm{g}$ cloprostenol (Oestrophan, Ferring-Léčiva, Prague, Czech.Republic) and $100 \mu \mathrm{g}$ of lecirelin pro toto (Supergestran, Ferring-Léčiva, Prague, Czech Republic) at the same time during luteal phase of the sexual cycle in group I, II and III.

Group I

Detection of oestrus was performed twice daily. Ovarian structures were evaluated by transrectal ultrasonography (Aloka SSD 500, $5 \mathrm{MHz}$ linear-assay probe, Tokyo, Japan) daily from the day of treatment (day 0 ) to the occurrence of a new luteal phase (new corpus luteum). Follicles $>3 \mathrm{~mm}$ in diameter and corpora lutea were individually identified by reference to their position and diameter in sequential images.

Group II

Ultrasonographical examination of ovarian structures were performed on the day of treatment (day 0) and on days 3, 7 and 14 after treatment. In addition, peripheral blood samples for progesterone determination by ELISA were withdrawn on days 0,3 and 7 after treatment. Development of luteal structures after simultaneous administration of cloprostrenol and lecirelin was also evaluated. 
Group III

The detection of oestrus was performed twice daily and the cows in oestrus were inseminated. Ultrasonographical examination was performed on days 0 (day of treatment), 14 and 28. The time and intensity of oestrus after treatment and ovarian structures on days 0,14 and 28 as well as conception rate were evaluated. Only the cows with symptoms of oestrus during 28 days after treatment were included in the evaluation.

Student's $t$-test was used for statistical analysis.

\section{Group I}

\section{Results}

Various intensive symptoms of oestrus were detected in 9 of 15 synchronized cycles during observation (in 4 cases between days 7 and 8 after treatment, in 5 cases between days 10 and 17). Corpora lutea disappeared within 5 days after treatment in all synchronized cycles. The number of small $(3-6 \mathrm{~mm})$ follicles decreased, medium $(7-10 \mathrm{~mm})$ and large $(>10 \mathrm{~mm}$ ) follicles disappeared during 3 to 4 days after the treatment and the number of small follicles increased again on the day 3 and 4 in most cases (Fig. 1). New medium and large follicles with characteristics of the dominance ( $>2 \mathrm{~mm}$ larger than others with increase of the difference during 3 following days) occurred within days 4 and 8 after treatment. These follicles ovulated or underwent atresia and disappeared. Ovulation occurred in 1 of 15 synchronized sexual cycles on the day 3 and in 6 of 15 synchronized cycles between days 7 and 9 after treatment. During other 6 synchronized sexual cycles the cows ovulated between days 10 and 17. Ovulation did not occur and luteal cysts developed in 2 synchronized cycles.

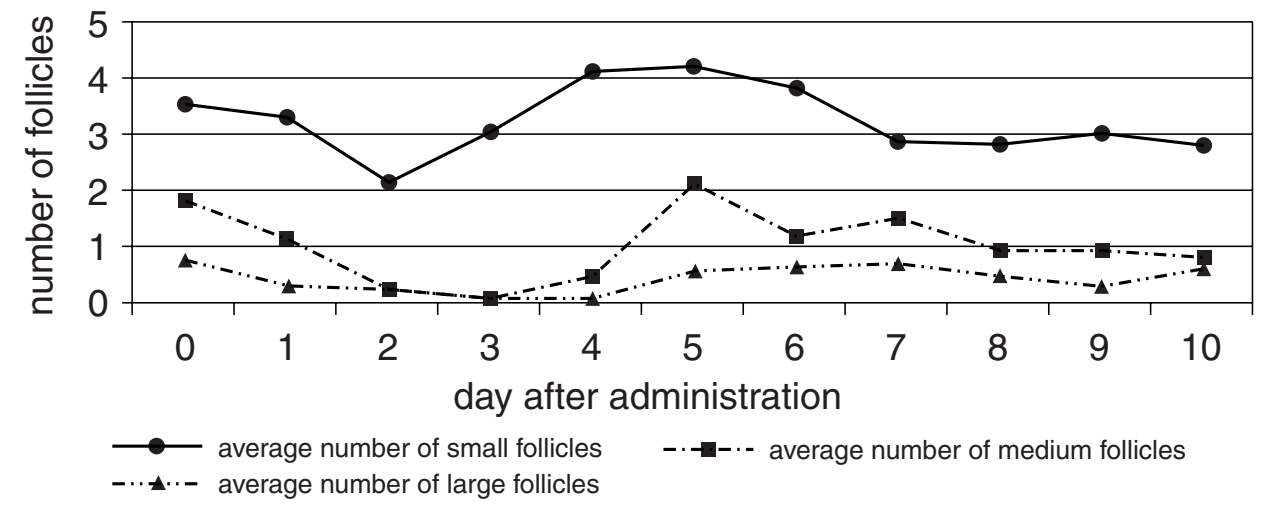

Fig.1. Occurrence of small (3-6 mm), medium $(7-10 \mathrm{~mm})$ and large ( $>10 \mathrm{~mm})$ follicles on ovaries during 10 days after simultaneous administration of $\mathrm{PGF}_{2} \alpha$ and $\mathrm{GnRH}$ in cows.

Group II $(\mathrm{n}=12)$

Ovulation occurred in 5 cows until day 3 after treatment (disappearance of the dominant follicle on the day 3 , new corpus luteum and except 1 cow concentration of progesterone above $1 \mathrm{ng} / \mathrm{ml}$ on the day 7). Only 2 of these cows showed symptoms of oestrus. Four cows ovulated between days 3 and 14 after treatment ( 2 cows - new corpus luteum and concentration of progesterone above $1 \mathrm{ng} / \mathrm{ml}$ on the day $7 ; 2$ cows - new corpus luteum on the day 14). Symptoms of oestrus were found in 3 of these cows. Ovulation was not proved in 3 cows until day 14 (absence of a new corpus luteum on days 7 and 14) and luteal cysts developed in 1 of them. Concentration of peripheral progesterone decreased in all observed cows on the day 3 after treatment and it slightly increased again in most of them (Fig. 2). We found total values $2.40 \pm$ $0.989,0.22 \pm 0.054$ and $0.44 \pm 0.323 \mathrm{ng} / \mathrm{ml}$ on days 0,3 and 7 , respectively. Differences between progesterone concentrations on days 0 and 3, 3 and 7, 0 and 7 were significant $(p<0.01)$. 


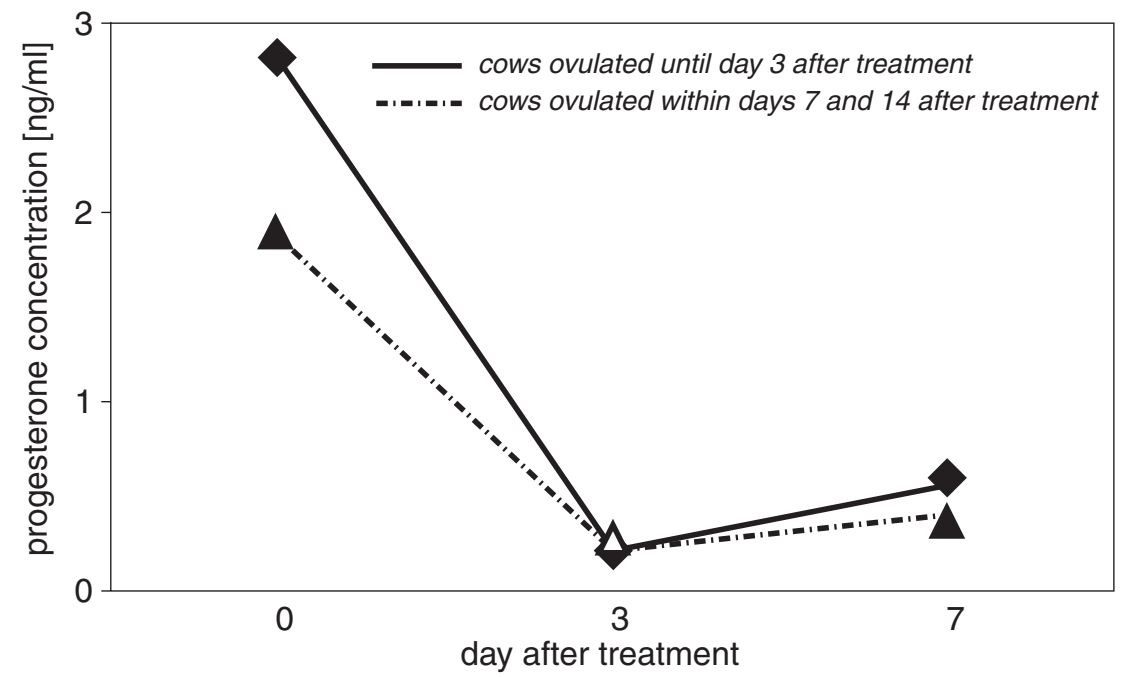

Fig. 2. Progesterone concentration in peripheral blood after simultaneous administration of $\mathrm{PGF}_{2} \alpha$ and $\mathrm{GnRH}$ in cows ovulated until day 3 in comparison with cows ovulated between day 7 and 14 after treatment.

Group III $(n=20)$

Occurrence of oestrus (days 3 - 25, on average day 7 after treatment) as well as intensity of oestrus symptoms were variable in 15 of 20 cows. Four cows were not inseminated because of low intensity of oestrus symptoms and 5 cows did not show any symptoms of oestrus during observation. But corpora lutea were found in 4 of 5 anoestrous cows on day 14 or 28 after treatment. Acyclicity was diagnosed in one cow. Total conception rate $(\mathrm{n}=$ 11) after the first insemination was $41 \%$. The majority of oestrus $(n=9)$ occurred between days 3 and 8 after treatment (Table 1).

Table 1

Occurrence of oestrus after simultaneous administration of $\mathrm{PGF}_{2} \alpha$ and $\mathrm{GnRH}$ in cows.

\begin{tabular}{l|l|l|l|l|l|l|l|l|l} 
day after treatment & 3 & 4 & 7 & 8 & 9 & 12 & 16 & 24 & 25 \\
\hline number of cow in oestrus & 4 & 1 & 1 & 3 & 2 & 1 & 1 & 1 & 1
\end{tabular}

Discussion

Ultrasonographical detection of pregnancy (from day 21 or 23 after insemination) at 14 day intervals represents the part of general periodical control of reproduction in dairy farms so that these examinations ase usually performed between day 21 (23) and 35 (37) after insemination. High percentage of non-pregnant cows after insemination are not detected for oestrus because almost half of the oestrus in normal cycling dairy cows may not be detected and effectiveness of the oestrus detection is generally low (Barr 1975; Rounsaville et al. 1976; Pankowski et al. 1995). Therefore, the examinations demonstrate luteal phase of the sexual cycle in most of the non-pregnant cows. In our previous observation we found in accordance with other authors (Noakes 1997) that one of the important causes of unsuccesful inseminations in rebreeding cows represents delayed ovulation (Doležel et 
al. 1998). For this reason induction/synchronization of estrus with predictable time of ovulation in inseminated but non-pregnant cows is necessary to be performed as soon as possible. Nevertheless, the time of ovulation after $\mathrm{PGF}_{2} \alpha$ is variable and "Ovsynch" method (GnRH - 7 days $-\mathrm{PGF}_{2} \alpha-2$ days $-\mathrm{GnRH}-1$ day -insemination) is a too long protocol (10 days from the $1^{\text {st }}$ treatment to insemination). For this reason simple protocol of the oestrus synchronization with control of the follicle development including single treatment by administration of $\mathrm{PGF}_{2} \alpha$ and $\mathrm{GnRH}$ in the same time coud be indicated in these cases.

Decrease of a number of large follicles after GnRH treatment was reported by several authors (Guilbault et al. 1990; Macmillan and Thatcher 1991). In our experiment the number of medium and large follicles decreased during the first 2 days after GnRH treatment. These results evidence termination of the contemporary follicular wave. But GnRH is effective only in the presence of functional dominant follicle during its growing and the $1^{\text {st }}$ part of the static phase but not during its regressing phase (Silcox et al. 1993). In addition follicle LH receptors decrease as the dominant follicle achieves a static phase (Rollos s on et al. 1994; B odenstainer et al. 1996)). That application of GnRH does not influence the dominant follicle in the $2^{\text {nd }}$ part of the static phase or in regressing phase which undergoes atresia in natural way. The data show that GnRH eliminates the large follicles in dependence on the phase of sexual cycle as well as the phase of follicular cycle by ovulation or atresia. Dominant estrogen active follicle in the growing phase generaly ovulates after $\mathrm{GnRH}$ administration during the follicular as well as luteal phase of the sexual cycle (Prescott et al. 1992; Schmitt et al.1996). We found a new corpus luteum until day 3 after simultaneous application of $\mathrm{PGF}_{2} \alpha$ and $\mathrm{GnRH}$ during various stage of the luteal phase of the sexual cycle only in one of 15 synchronized sexual cycles in group 1 and in 5 of 12 observed cows in group 2. Ovulation and development of new corpora lutea could be inhibited by interaction of $\mathrm{PGF}_{2} \alpha$ and GnRH in control of ovary function or it coud be inhibited by stage of the follicle development with follicles which are not ready for maturation and ovulation (follicular wave before selection of the dominant follicle or presence of the dominant follicle in static or regressing phase). These follicles do not ovulate and undergo atresia. Influence of the stage of follicle development to ovulation rate after GnRH exerts itself via the stage of the sexual cycle in the time of application because two or three follicular waves fluctuate during sexual cycle in most cows. Kohram et al. (1998) found ovulation only in 2 of 6 observed cows which were treated by GnRH during expected static phase of the dominant follicle development between days 15 and 18 of the oestrus cycle. Vasconcelos et al. (1999) reported lower ovulation rate between days 1 and 4, 10 and 16 than between days 5 and 9, 17 and 21 , respectively. In our experiment we treated cows bearing distinct corpora lutea in sonographical image. It can be assumed that the majority of the treatments were performed during maximal development of corpora lutea between days 9 and 16 of the sexual cycle when ovulation rate after $\mathrm{GnRH}$ is low.

The new corpus luteum after GnRH administration disappeared till day 8 after treatment. Estrus occurred in this cow on the day 12 after treatment. Short lifespan of the corpus luteum is in accordance with findings that $\mathrm{GnRH}$ administration early after $\mathrm{PGF}_{2} \alpha$ can induce ovulation of the premature dominant follicle with following shorter luteal function (Taponen et al. 1999). Mechanisms of subnormal luteal function may include inadequate preovulatory follicular development (Armstrong and Hansel 1959), decreased luteotrophic support (A s sey et al. 1993), recently premature release of $\mathrm{PGF}_{2} \alpha$ ( $\mathrm{Lish}$ man and Inskeep 1991; Garverick et al. 1992).

Luteinization of the dominant follicles without ovulation (luteal cysts) were found in two synchronized cycles. Despite of the development of ovarian cyst after GnRH in the frame of synchronization of estrus has not well documented. Experience from our laboratory show that it is possible during Ovsynch protocol as well. 
As was stated above, the decrease of the total number of medium and large follicles and again the increase of the number of these follicles on the day 3 or 4 after treatment in our experiment is evidence of a recruitment of a new follicular wave. Occurrence of a new follicular wave on day 3 or 4 after GnRH administration is well documented (review Twagiramungu et al. 1995; Pursley et al. 1995; Burke et al. 1996; Kohram et al. 1998). Probably two mechanisms are responsible for recruitment of new follicular wave after GnRH. Firstly, it is caused by removal/disappearance of the dominant follicle. Because paracrine function of the active dominant follicle prevents from development of other follicles (Driancourt 1991; Fortune et al. 1991) and its endocrine function includes secretion of FSH inhibiting factors such as inhibin (Guilbault et al. 1993) elimination of the dominant follicle represents removal of the follicular development inhibition. Increase of FSH concentration on days 1 or 2 and new follicular wave occurs on the day 3 or 4 after dissapearance of the dominant follicle in natural sexual cycle (Ko et al. 1991; Adams et al. 1992). Secondly, effect of exogenous GnRH is exerted directly via gonadotropin secretion. GnRH stimulates LH as well as FSH secretion. GnRH-induced release of FSH occurrs within 2 to 4 hours after treatment (Chenault et al. 1990; Rettmer et al. 1992). As was stated above increase of FSH concentration precedes a new follicular wave about 2 or 3 days in natural conditions.

In spite of a synchonized occurrence of new follicular waves and absence of corpora lutea after treatment, the time of ovulation varied in our experiment. Only dominant follicles in 6 of 15 synchronized sexual cycles ovulated in the time expected ( 7 to 9 days after treatment). It was 5 to 7 days after occurrence of new follicular waves and the interval is comparable with the length of natural follicular wave. Length of the follicular waves in synchronized sexual cycles with ovulation between days 10 and 17 after treatment was variable or new follicular waves occurred. It could be caused by higher concentration of progesterone after incompleted luteolysis by $\mathrm{PGF}_{2} \alpha$ or in the presence of luteinized follicles or atypical new corpora lutea after GnRH which were not recorded by ultrasonography. Slightly increased progesterone concentration in most of the cows on the day 7 after treatment in experimental group 2 supports this assumption.

In conclusion, simultaneous administration of $\mathrm{PGF}_{2} \alpha$ and $\mathrm{GnRH}$ in cows during the luteal phase of the sexual cycle does not represent a sufficiently efficient method of synchronization of estrus in cows. Nevertheless, the majority of oestrus and ovulation can be expected on the days 3 and 8 after treatment. Efficiency of this method is probably influenced by phase of the sexual cycle at the time of treatment.

\section{Účinek současné aplikace $\mathrm{PGF}_{2} \alpha$ a GnRH na folikulární vývoj, říji a dobu ovulace u krav}

Cílem práce bylo synchronizovat ř́iji u krav současnou aplikací $\mathrm{PGF}_{2} \alpha$ a GnRH. Synchronizace ř́ije byla provedena opakovaně u 5 ustájených krav na klinice univerzity (skupina I) a u 32 cyklujících mléčných krav na farmách (skupina II a III). Ve skupině I bylo sledováno celkem 15 synchronizovaných pohlavních cyklů. Ř́je byla synchronizována současnou intramuskulární aplikací $500 \mu \mathrm{g}$ cloprostenolu a $100 \mu \mathrm{g}$ lecirelinu pro toto (spec. Oestrophan a Supergestran, Ferring-Léčiva, Praha, ČR) během luteální fáze pohlavního cyklu. Ve skupině I byly krávy vyšetř̌ovány transrektální sonografií denně od ošetření (den 0 ) do objevení se nové luteální fáze a byly hodnoceny ovariální struktury. Ve II. skupině $(\mathrm{n}=12)$ bylo sonografické vyšetření ovariálních struktur provedeno v den ošetření (den 0$)$ a dále $\mathrm{v}$ den 3,7 , a 14 . Navíc byly v den 0,3 a 7 odebrány vzorky periferní krve k vyšetření koncentrace progesteronu metodou ELISA. Ve skupině III $(n=20)$ po ošetření byla 2 krát denně prováděna detekce říje a sonografické vyšetření pohlavních orgánů bylo provedeno v den 0 (den ošetření), 14 a 28. Říjející se krávy v této skupině byly inseminovány a byla hodnocena úroveň koncepce. Ve skupině I ve všech synchronizovaných pohlavních cyklech nastoupila nová folikulární vlna do 3 . nebo 4. dne po ošetření a ovulace proběhla 
u 1 synchronizovaného cyklu v den 3 , u 6 cyklů mezi 7. a 9. dnem a u 6 cyklů mezi 10. a 17 . dnem. U zbývajících dvou synchronizovaných cyklů $\mathrm{v}$ této skupině ovulace neproběhla a vyvinuly se luteální cysty. Ve II. skupině ovulace proběhla u 5 krav do 3 dnů po ošetření a u 4 krav mezi 3. a 14. dnem. Do 14 dnů po ošetření ovulace nebyla prokázána u 3 krav a u jedné z nich se objevily luteální cysty. Celková koncentrace progesteronu v den 0,3 a 7 byla $2,40 \pm 0,989,0,22 \pm 0,054$ and $0,44 \pm 0,323 \mathrm{ng} / \mathrm{ml}$. Ve III. skupině byl nejčastější termín ř́ije 3. a 8. den po ošetření a celková úroveň koncepce byla $41 \%$. Současná aplikace $\mathrm{PGF}_{2} \alpha$ a GnRH během luteální fáze pohlavního cyklu nepředstavuje dostatečně účinnou metodu synchronizace říje i krav. Nicméně většina říjí a ovulací probíhá 3 . a 8. den po ošetření.

\section{Acknowledgements}

The authors wish to thank agricultural producers AGRODRUŽSTVO BRŤOV - LIPU゚VKA, AGRIA a. s. Nížkovice, GENAGRO ŘÍČANY a.s. which make research possible in their dairy farms. This study was supported by grant No.161700002 of Ministry of Education, Youth and Sports.

\section{References}

ADAMS, G. P., MATTERI, R. L., KASTELIC, J. P., KO, J. C. H., GINTHER, O. J. 1992: Association between surges of follicle-stimulating hormone and the emergence of follicular waves in heifers. J. Reprod. Fertil. 94: 177 ARMSTRONG, D. T., HANSEL, W. 1959: Alteration of the bovine estrous cycle with oxytocin. J. Dairy Sci. 42: 533-542

ASSAY, R. J., PURWANTARA, B., GREVE, T., HYTTEL, P., SCHMIDT, M. H. 1993: Corpus luteum size and plasma progesterone levels in cattle after cloprostenol-induced luteolysis. Theriogenology 39: 1321-1330

BARR, H. L. 1975: Influence of estrus detection on days open in dairy herds. J. Dairy Sci. 58: 246-247

BODENSTAINER, K. J., WILTBANK, M. C., BERGFELT, D. R., GINTHER, O. J. 1996: Alterations in follicular estradiol and gonadotropin receptors during development of bovine antral follicles. Theriogenology 45: 499-512

BURKE, J. M., DE LA SOTA, R. L., RISCO, C. A., STAPLES, C. R., SCHMITT, E. J. P., THATCHER, W. W. 1996: Evaluation of timed insemination using a gonadotropin-releasing hormone agonist in lactating dairy cows. J. Dairy Sci. 79: 1385-1393

CHENAULT, J. R., KRATZER, D. D., RZEPKOWSKI, R. A., GOODWIN, M. C. 1990: LH and FSH response of Holstein heifers to fertirelin acetate, gonadorelin and buserelin. Theriogenology 34: 81

DOLEŽEL, R., ČECH, S., LOPATÁŘOVÁ, M. 1998: Delayed ovulation and embryonic mortality in subfertile cows. Reprod.Dom.Anim., Suppl.5: 127 abstract

DRIANCOURT, M. A. 1991: Follicular dynamics in sheep and cattle. Theriogenology 35: 55-79

FORTUNE, J. E., SIROIS, J., TURZILLO, A. M., LAVOIR, M. 1991: Follicle selection in domestic ruminants. J. Reprod. Fert. Suppl. 43: 187 - 198

GARVERICK, H. A., ZOLLERS, W.G., JR.SMITH, M. F. 1992: Mechanism associated with corpus luteum lifespan in animals having normal or subnormal luteal function. Anim. Reprod. Sci. 28: 111-124

GUILBAULT, L. A., LUSSIER, J. G., GRASSO, F., MATTON, P. 1990: Influence of a GnRH analogue on follicular dynamics in cows pretreated or not with FSH-P. Theriogenology 33: 240 (abstract)

GUILBAUlT, L. A., ROUILLER, P., MATTON, P., GLENCROSS, R. G., BEARD, A. J., KNIGHT, P.G. 1993 Relationships between the level of atresia and inhibin contents ( $\alpha$ subunit and $\alpha-\beta$ dimer) in morphologically dominant follicles during their growing and regressing phases of development in cattle. Biol. Reprod. 48: 268

KO, J. C. H., KASTELIC, J. P., DEL CAMPO, M. R., GINTHER, O. J. 1991: Effect of a dominant follicle on ovarian follicular dynamics during the oestrous cycle in heifers. J. Reprod.Fertil. 91: 511

KOHRAM, H., TWAGIRAMUNGU, H., BOUSQUET, D., DUROCHER, J., GUILBAULT, L. A. 1998: Ovarian superstimulation after follicular wave synchronization with $\mathrm{GnRH}$ at two different stages of the estrous cycle in cattle. Theriogenology 49: 1175-1186

LARSON, R. L., CORAH, L. R., PETERS, C. W. 1996: Synchronization of estrus in yearling beef heifers with the melengestrol acetate/prostaglandin F 2 asystem: efficiency of timed insemination 72 hours after prostaglandin treatment. Theriogenology 45: 851-863

LISHMAN, A. W., INSKEEP, E. K. 1991: Definciencies in luteal function during re-initiation of cyclic breeding activity in cows and in ewes. S. Afr. J. Anim. Sci. 21: 59-75

MACMILLAN, K. L., THATCHER, W. W. 1991: Effect of an agonist of gonadotropin-releasing hormone on ovarian follicles in cattle. Biol. Reprod. 45: 883

NOAKES, D. E. 1997: Fertility and Obstetrics in Cattle. Blackwell Science Ltd, London, $2^{\text {nd }}$ ed., $146 \mathrm{p}$

PANKOWSKI, J. W., GALTON, D. M., ERB, H. N., GUARD, C. L., GROHN, Y. T. 1995: Use of prostaglandin $\mathrm{F}_{2} \alpha$ as a postpartum reproductive management tool for lactating dairy cows. J. Dairy Sci. 62: 1167-1170

PIERSON, R. A., GINTHER, O. J.1987: Follicular populations during the estrous cycle in heifers. I.The influence of day. Anim. Reprod. Sci. 14: 165-176 
PIERSON, R. A., GINTHER, O. J. 1988: Follicular population during the estrous cycle in heifers. III. Time of selection of the ovulatory follicle. Anim. Reprod. Sci. 16: 81-95

PRESCOTT, R. E., SILCOX, R. W., BYERLEY, D. J., CAUDLE, A. B., KISER, T. E. 1992: Effect of GnRH on the dominant follicle of the first follicular wave in beef cows. J. Anim. Sci. 70 (Suppl.1): 231 abstr

PURSLEY, J. R., MEE, M. O., WILTBANK, M. C. 1995: Synchronization of ovulation in dairy cows using PGF $2 \alpha$ and GnRH. Theriogenology 44: 915-923

PURSLEY, J. R., KOSOROK, M. R., WILTBANK, M. C. 1997: Reproductive management of lactating dairy cows using synchronization of ovulation. J. Dairy Sci. 80: 301-306

RAJAMAHENDRAN, R., WALTON, J. S. 1988: Follicular development and corpus luteum formation in postpartum dairy cattle. In: Proc. $11^{\text {th }}$ Int. Congr. Anim. Reprod. Artif. Insem. University College, Dublin, 60

RETTMER, I., STEVENSON, J. S., CORAH, L. R. 1992: Endocrine responses and ovarian changes in inseminated dairy heifers after an injection of a GnRH agonist 11 to 13 days after estrus. J. Anim. Sci. 70: 508

ROLLOSSON, M. M., CRIM, J. W., SILCOX, R. W., KISER, T. E. 1994: Density of [ ${ }^{125}$ I] $]$ hG binding to the dominant follicle of the first wave of the estrous cycle in cows. J.Dairy Sci. 77 (Suppl.1): 231 (Abstr.)

ROUNSAVILlE, T. R., OLTENACU, P. A., MILLIGAN, R. A., FOOTE, R. H. 1979: Effect of heat detection, conception rate, and culling policy on reproductive performance in dairy herds. J. Dairy Sci. 62: 1435-1442

SCHMITT, E. J., DIAZ, T., BARROS, C. M., DE LA SOTA, R. L., DROST, M., FREDRIKSSON, E. W., STAPLES, C. R.,THORNER, R., THATCHER, W. W. 1996: Differential response of the luteal phase and fertility in cattle following ovulation of the first-wave follicle with human chorionic gonadotropin or an agonist of gonadotropin-releasing hormone. J. Anim. Sci. 74: 1074-1083

SILCOX, R. W., POWEL, K. L., KISER, T. E. 1993: Ability of dominant follicles (DF) to respond to exogenous GnRH administration is dependent on their stage of development. J. Anim. Sci.71: (Suppl. 1), 219 abstract

SIROIS, J., FORTUNE, J. E. 1988: Ovarian follicular dynamics during the estrous cycle in heifers monitored by real-time ultrasonography. Biol. Reprod. 39: 308-316

TAPONEN, J., KATILA, K., RODRIGUEZ-MARTÍNEZ, H. 1999: Induction of ovulation with gonadotropinreleasing hormone during proestrus in cattle: influence on subsequent follicular growth and luteal function. Anim.Reprod. Sci. 55: 91-105

TWAGIRAMUNGU, H., GUILBAULT, L. A., DUFOUR, J. J. 1995: Synchronization of ovarian follicular waves with a gonadotropin-releasing hormone agonist to increase the precision of estrus in cattle: a review. Anim. Sci. 73: $3141-3151$

VASCONCElOS, J. L. M., SILCOX, R. W., ROSA, G. J. M., PURSLEY, J. R., WILTBANK, M. C. 1999: Synchronization rate, size of the ovulatory follicle, and pregnancy rate after synchronization of ovulation beginning on different days of the estrous cycle in lactating dairy cows. Theriogenology 52: 1067-1078

XU, Z. Z., BURTON, L. J., MACMILLAN, K. L. 1997: Reproductive performance of lactating dairy cows following estrus synchronization regimens with $\mathrm{PGF}_{2} \alpha$ and progesterone. Theriogenology 47: 687-701 